\title{
Early vulvar and umbilical incisional scar recurrence of cervical squamous cell carcinoma: Earlier than usually expected
}

\section{Skuamöz hücreli servikal karsinomun erken vulvar ve umbilikal insizyonel skar rekürrensi: Beklenilenden daha erken}

\author{
Hüseyin Çağlayan Özcan ${ }^{1}$, Aynur Mustafa ${ }^{1}$, Zehra Bozdağ ${ }^{2}$, Seyhun Sucu ${ }^{1}$, Mete Gürol Uğur ${ }^{1}$, Özcan Balat ${ }^{1}$ \\ ${ }^{1}$ Gaziantep University Faculty of Medicine, Department of Obstetrics and Gynecology, Gaziantep, Turkey \\ ${ }^{2}$ Gaziantep University Faculty of Medicine, Department of Pathology, Gaziantep, Turkey
}

\begin{abstract}
Cutaneous metastasis is considered as a hazardous condition depending on the mean survival around 9 months, which usually originates from cancers of the breast, lung, ovary, colon, and rarely from the cervix. The crucial prognostic factor of cutaneous metastasis depends on the period between the primary malignancy and cutaneous metastasis. We report two cases of the unusual presentation of squamous cell cancer of the cervix that developed vulvar and umbilical metastasis in the $5^{\text {th }}$ month of primary treatment. Both of our patients survived for 11 months following the primary treatment. In addition, our first case is the earliest vulvar recurrence of cervical carcinoma in the English literature following appropriate medical and surgical management.

Keywords: Squamous cell cervical cancer, umbilical metastasis, vulvar metastasis

$\ddot{\mathrm{O} z}$

Deri metastazı ortalama sağkalım süresi 9 ay olan, genellikle meme, akciğer, over, kolon ve nadiren de serviksten köken alan tehlikeli bir durumdur. Deri metastazı ve primer malignensi arasındaki zaman deri metastazının oluşumunda çok önemli bir prognostik faktördür. Primer tedavinin 5. ayında gelişen skuamöz hücreli kanserin çok nadir görülen vulvar ve umbilikal metastaz olgularından ikisini sunuyoruz. Olgularımızın ikisi de primer tedavi sonrası 11 ay yaşadılar. Sunmuş olduğumuz ilk hasta uygun medikal ve cerrahi sonrasında serviks kanserinin İngilizce literatürdeki en erken vulvar rekürrensi olan olgudur.
\end{abstract}

Anahtar Kelimeler: Skuamöz hücreli serviks kanseri, umbilikal metastaz, vulvar metastaz

\section{Introduction}

Cervical cancer recurrence depends on the cancer's clinical stage and may manifest as local or distant metastasis in different organs. Recurrence occurs most commonly in the pelvis, which includes the parametrium or lymph nodes, and in the vagina. Recurrence can rarely occur in the skin, ranging between 0.1$1.3 \%$. In most cases, they manifest as an asymptomatic dermal/ subcutaneous plaque, ulcer or nodule ${ }^{(1)}$.

We report two unusual presentations of cervical squamous cell carcinoma with early vulvar and umbilical metastasis.

\section{Case Reports}

Case 1

A woman aged 41 years was admitted to a state hospital with pelvic pain, urinary burning, and vaginal bleeding. The patient was referred to our hospital after a cervical biopsy revealed cervical squamous cell carcinoma. On our physical examination, we observed an exophytic necrotic mass measuring $8 \times 9 \mathrm{~cm}$ confined to the cervix with no parametrial invasion. According to the International Federation of Gynecology and Obstetrics classification, we established the diagnosis as stage $1 \mathrm{~b}-2$

Address for Correspondence/Yazışma Adresi: Hüseyin Çağlayan Özcan, MD,

Gaziantep University Faculty of Medicine, Department of Obstetrics and Gynecology, Gaziantep, Turkey

Phone: +90 3423606060 E-mail: ozcan.caglayan8@hotmail.com

Received /Geliş Tarihi: 13.02.2017 Accepted/Kabul Tarihi: 27.04.2017

${ }^{\oplus}$ Copyright 2017 by Turkish Society of Obstetrics and Gynecology

Turkish Journal of Obstetrics and Gynecology published by Galenos Publishing House 
cervical cancer. We excised the mass through the vagina route and performed a type 3 radical hysterectomy (Wertheim) with pelvic-paraaortic lymph node dissection followed by radiotherapy. In the fifth month after surgical treatment, we observed a 2x3-cm ulcerated nodular vulvar lesion (Figure 1). The lesion in the vulva was excised following abdominopelvic computerized tomography (CT) imaging, which revealed no significant pathology. The biopsy specimen showed squamous cell carcinoma (Figure 2). A paclitaxel and carboplatin combined chemotherapy protocol was used. Following 2 cycles of chemotherapy, positron emission tomography-CT revealed diffuse metastases in the abdominopelvic site. Despite and alternative protocol (gemcitabine and bevacizumab) administration, there was no response. The patient died in the $11^{\text {th }}$ month of the postoperative period.

\section{Case 2}

A woman aged 54 years who was post-menopausal presented with vaginal bleeding that had persisted for 3 months. A vaginal examination revealed a cervical mass measuring $1 \times 1.5 \mathrm{~cm}$. Histologic examination of the mass showed cervical squamous cell carcinoma. A Wertheim operation was performed and there was no lymph node involvement and the mass had negative

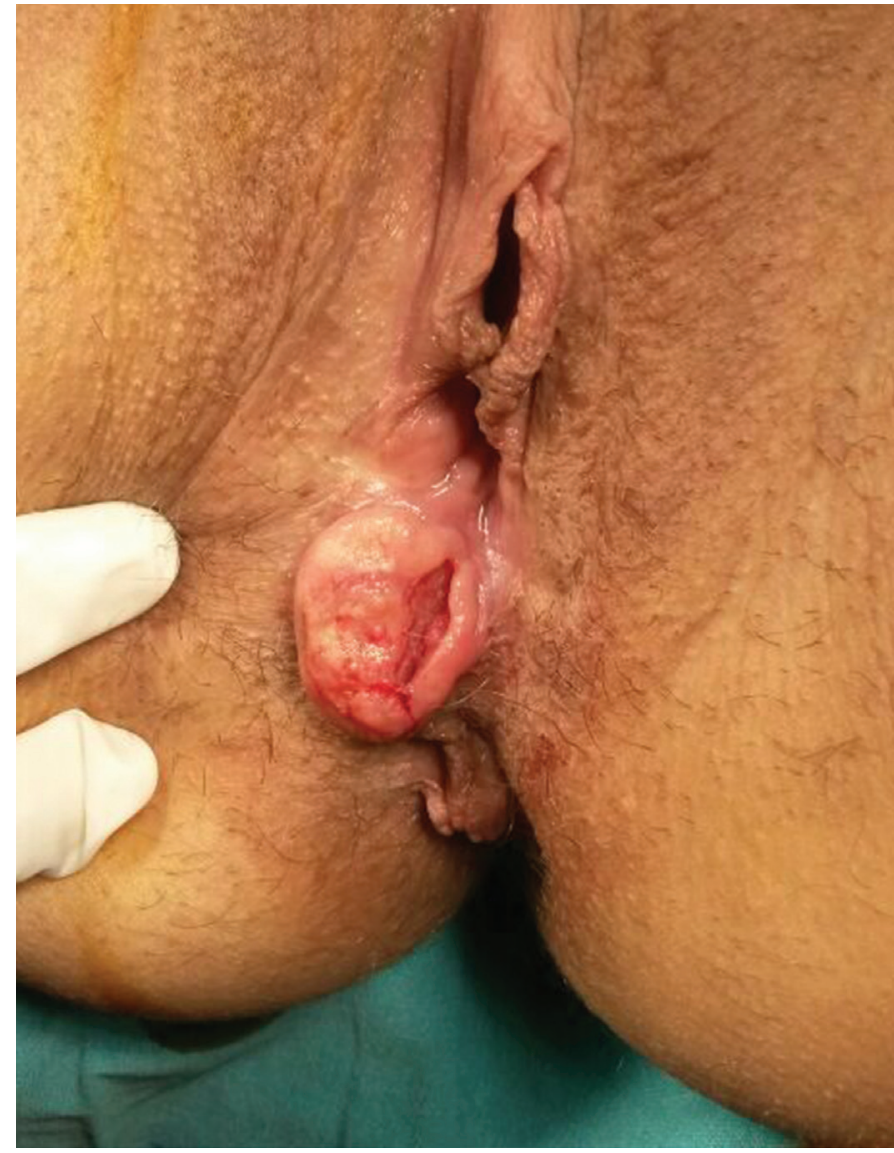

Figure 1. A 2x3-cm ulcerated fragile, firm, nodular lesion with irregular boundaries on the right labium majus with focal central hemorrhage surgical borders (stage 1b-1). A Papanicolaou smear was obtained from the vaginal cuff 3 months later and the result was negative. The patient presented with severe abdominal pain, which was localized along the incisional scar region of her umbilicus five months after the primary surgical treatment. Abdominal CT revealed an umbilical mass measuring $4 \times 4.5 \mathrm{~cm}$ in diameter (Figure 3). We considered that the fixed mass was inoperable; it included all layers of the umbilical wall and extended from umbilicus to the upper anterior abdominal wall with massive adhesions. We performed a partial resection of the mass and pathologic examination revealed metastatic squamous cell carcinoma. Two cycles of chemotherapy, including paclitaxelcarboplatin in the first cycle and bevacizumab-gemcitabine in the second cycle, and radiotherapy was administered. The patient died in the $11^{\text {th }}$ month of her medication.

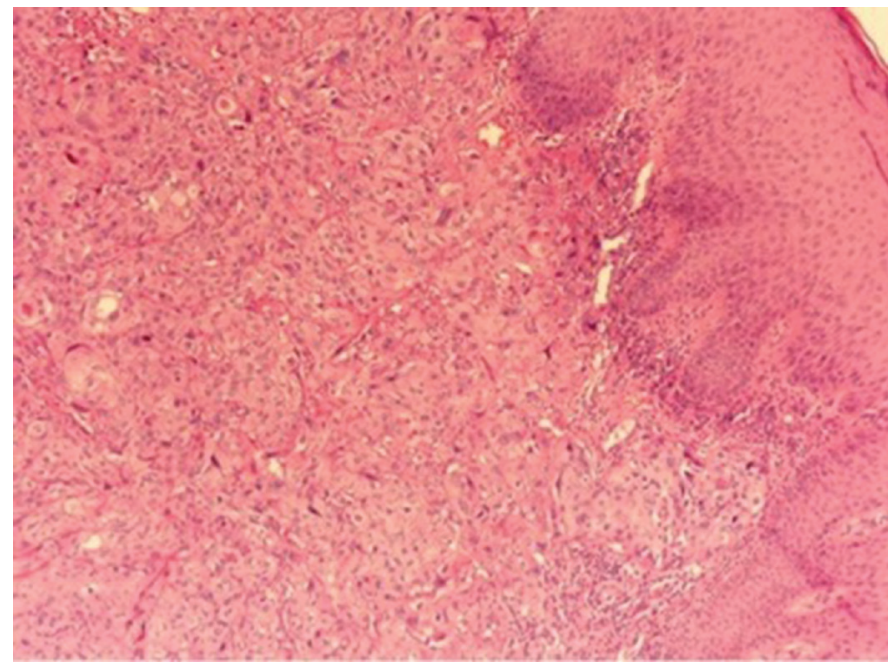

Figure 2. Infiltrating tumor nests consisting of atypical squamous cells with large abundant eosinophilic cytoplasm and a large vesicular nucleus with prominent nucleoli

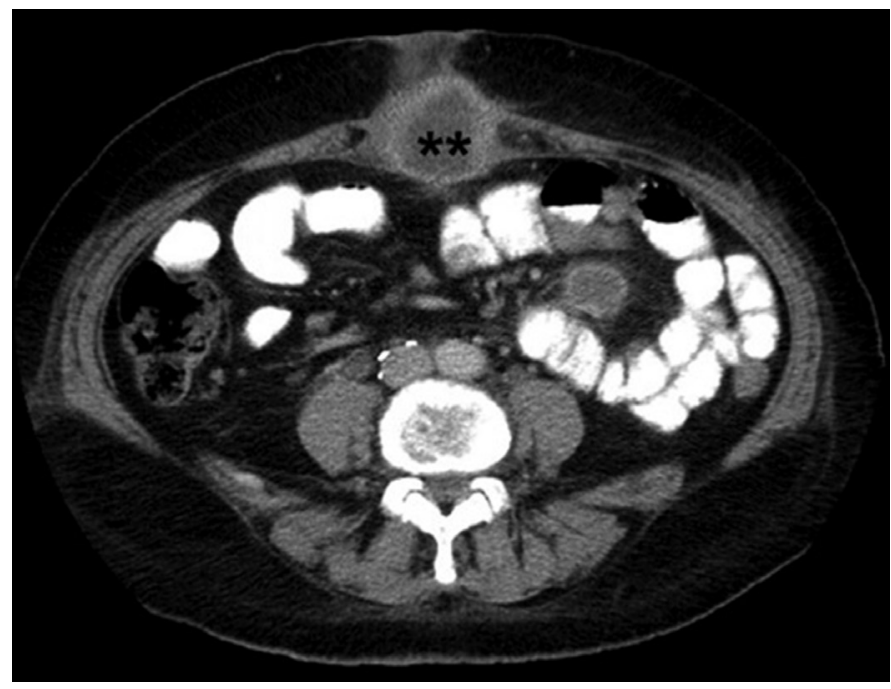

Figure 3. Computerized tomography image of metastatic umbilical mass 
Table 1. Reported cases of vulvar metastasis in cervical cancer

\begin{tabular}{lllllll}
$\begin{array}{l}\text { Patient } \\
\text { no. }\end{array}$ & Year & First author & $\begin{array}{l}\text { Numberof } \\
\text { patients }\end{array}$ & $\begin{array}{l}\text { Treatment } \\
\text { taken }\end{array}$ & $\begin{array}{l}\text { Appearance of lesions } \\
\text { after therapy }\end{array}$ & \begin{tabular}{l} 
Sites of metastasis \\
\hline 1
\end{tabular} \\
\hline 2 & 2005 & Srivastava $^{(4)}$ & 1 & Surgery + RT & 3.5 years & Incisional skin metastasis, vulvar metastasis \\
\hline 3 & 2010 & Grabiec $^{(6)}$ & 1 & Surgery + RT & No data available & Vulvar and perineal metastasis \\
\hline 4 & 2011 & Deka $^{(2)}$ & 1 & CRT & 6 years & Vulvar metastasis \\
\hline 5 & 2013 & Rimmond $^{(1)}$ & 1 & CRT & 2 years & Vulvar metastasis \\
\hline RT: Radiotherapy, CRT: Chemotherapy & & Surgery + CRT & 4.5 years & Vulvar metastasis
\end{tabular}

\section{Discussion}

Cutaneous metastasis usually originates from cancers of the breast, lung, ovary, colon, and rarely from the cervix. Cervical carcinoma metastases frequently occur in the vulva and anterior abdominal wall or scalp, extremities, and the umbilical surgical scar can be affected, albeit rarely ${ }^{(1)}$. Invasive interventions, including paracentesis, laparoscopy, and laparotomy can also play a role in metastases of the cervix ${ }^{(2)}$. In addition, cutaneous metastases have an incidence of $0.8 \%$ in treated cervical cancers $^{(3)}$. Adenocarcinoma and undifferentiated carcinoma of the cervix are the primary histopathologic types that contribute to cutaneous metastasis. However, there is no correlation between its prevalence and clinical stages ${ }^{(4)}$.

Cervical carcinoma can spread either locally or through lymphatic vessels. The lymphatic route usually follows pelvic, paraaortic and/or supraclavicular nodes, respectively. Cervical lymphatics are drained through pre-ureteral, post-ureteral, and uterosacral nodes, but these routes cannot clarify vulvar involvement. Vaginal-vulvar pathways and hematogenous invasion could be the possible routes of vulvar and umbilical incisional scar invasions, respectively. These theories have not been proven by either histologic or imaging methods. Tumor invasion to pelvic organs and the vulva can be explained by the close anatomic relationship ${ }^{(5)}$. Patients with cervical cancer metastasis can present with different symptoms. In our cases, painless skin lesions and severe abdominal pain localized in the umbilicus were the first signs of metastases during follow-up. It is very rare to detect cutaneous vulvar metastasis originating from cervical cancer before between 3.5 and 6 years after surgery ${ }^{(2,4)}$. However, this is the earliest vulvar metastasis (in the $5^{\text {th }}$ month of primary treatment) of cervical cancer in the English literature. A review of the relevant literature concerning vulvar metastasis is summarized in Table 1. In contrary, there are some reports regarding early umbilical recurrence of cervical cancer in the $4^{\text {th }}, 5^{\text {th }}$, and $6^{\text {th }}$ months of primary treatment ${ }^{(2,8,9)}$. There are approximately 17 reports regarding umbilical metastasis of cervical cancer in the literature $e^{(2,10-14)}$.

Cutaneous metastasis is considered as a hazardous condition; the mean life span is around 9 months. Regarding one study that included 1190 patients with cervical carcinoma, the incidence skin metastasis was $1.3 \%$, which increased with advanced clinical stage as follows: $0.8 \%$ in stage $1,1.2 \%$ in stages 2 and 3 , and increasing to $4.8 \%$ in stage 4 . The presence of such metastasis is associated with a high mortality rate within 2 years, regardless of the treatment procedure ${ }^{(15)}$. Therefore, the crucial prognostic factor depends on the period between the primary malignancy and cutaneous metastasis. In other words, earlier metastasis means poorer prognosis. Survival was 11 months in both of our cases, most probably due to the short recurrence period ( $5^{\text {th }}$ month) following the primary surgical treatment.

Palliative surgery, chemotherapy, radiation therapy alone and/or in combination with cisplatin-based chemotherapy are well-known treatment modalities in managing advanced recurrent disease ${ }^{(16)}$. Based on that, we applied platinum-based chemotherapy in both cases and concurrent radiotherapy after detecting vulvar and umbilical scar extensions, respectively. Nevertheless, there was no response and we administered an alternative protocol (gemcitabine and bevacizumab) in both cases, which may have prolonged survival to up to approximately one year.

In conclusion, cervical cancer rarely leads to vulvar and umbilical incisional scar metastasis, which can be accepted as a poor prognostic factor accompanied with short life span. Physicians should always keep in mind the likelihood of recurrence at these locations during follow-up in cases of cervical cancer. To the best of our knowledge, our first case is the earliest vulvar recurrence and our second case is one of the earliest recurrences of cervical carcinoma in the English literature following appropriate surgical and medical management.

\section{Ethics}

Informed Consent: Consent forms were filled out by our two patients.

Peer-review: Externally peer-reviewed.

\section{Authorship Contributions}

Concept: A.M., Ö.B., Design: Z.B., Data Collection or Processing: A.M., S.S., Analysis or Interpretation: M.G.U., H.Ç.Ö., Literature Search: H.Ç.Ö., S.S., Writing: H.Ç.Ö., M.G.U. Conflict of Interest: No conflict of interest was declared by the authors. 
Financial Disclosure: The authors declared that this study has received no financial support.

\section{References}

1. Kim WJ, Park HJ, Kim HS, Kim SH, Ko HC, Kim BS, et al. Vulvar metastasis from squamous cell carcinoma of the cervix clinically presenting as lymphangioma circumcriptum. Ann Dermatol 2011;23:64-7.

2. Deka D, Gupta N, Bahadur A, Dadhwal V, Mittal S. Umbilical Surgical and Vulvar Metastases Secondary to advanced cervical Squamous cell carcinoma: a report of two cases. Arch Gynecol Obstet 2010;281:761-4.

3. Bolli JA, Doering DL, Bosscher JR, Day TG Jr, Rao CV, Owens K, et al. Squamous cell carcinoma antigen: clinical utility in squamous cell carcinoma of uterine cervix. Gynecol Oncol 1994;55:169-73.

4. Srivastava K, Singh S, Srivastava M, Srivastava AN. Incisional skin metastasis of a squamous cell cervical carcinoma 3.5 years after radical treatment-a case report. Int J Gynecol Cancer 2005;15:11836.

5. Quinn MA, Benedet JL, Odicino F, Maisonneuve P, Beller U, Creasman WT, et al. Carcinoma of the cervix uteri. FIGO 6th Annual Report on the Results of Treatment in Gynecological Cancer. Int J Gynaecol Obstet 2006;95(Suppl 1):S43-103.

6. Grabiec M, Walentowicz M, Marszałek A. Multiple skin metastases to vulva from carcinoma of the cervical stump. Ginekol Pol 2010;81:140-3.

7. Richmond NA, Viera MH, Velazquez-Vega J, Kerdel FA. Cutaneous Metastasis of Cervical Adenocarcinoma to the Vulva. Dermatol Online J 2013;19:18172.

8. Naumann RW, Spencer S. An umbilical metastasis after laparoscopy for squamous cell carcinoma of the cervix. Gynecol Oncol 1997;64:507-9.

9. Liro M, Kobierski J, Brzoska B. Isolated metastasis of cervical cancer to the abdominal wall: a case report. Ginekol Pol 2002;73:704-8.

10. Martinez-Palones JM, Gil-Moreno A, Perez-Benavente MA, GarciaGimenez A, Xercavins J. Umbilical metastasis after laparoscopic retroperitoneal paraaortic lymphadenectomy for cervical cancer: a true port-site metastasis? Gynecol Oncol 2005;97:292-5.

11. Agostini A, Carcopino X, Franchi F, Cravello L, Lecuru F, Blanc B. Port site metastasis after laparoscopy for uterine cervical carcinoma. Surg Endosc 2003;17:1663-5.

12. Tun NM, Yoe L. Sister Mary Joseph Nodule: A Rare Presentation of Squamous Cell Carcinoma of the Cervix. Ochsner J 2015;15:256-8.

13. Samaila MO, Adesiyun AG, Waziri GD, Koledade KA, Kolawole AO. Cutaneous umbilical metastases in post-menopausal females with gynaecological malignancies. J Turk Ger Gynecol Assoc 2012;13:204-7.

14. Tseng MJ, Ho KC, Lin G, Yen TC, Tsai CS, Lai CH. Peritoneal metastasis in primary cervical cancer: a case report. Eu J Gynaecol Oncol 2007;28:225-8.

15. Imachi M, Tsukamoto N, Kinoshita S, Nakano H. Skin metastasis from carcinoma of the uterine cervix. Gynecol Oncol 1993;48:34954.

16. Behtash N, Ghaemmaghami F, Yarandi F, Ardalan FA, Khanafshar N. Cutaneous metastasis from carcinoma cervix at the drain site: a case report. Gynecol Oncol 2002;85:209-11. 